\title{
ANALYSIS OF THE PRODUCTION AND MARKETING OF ORGANIC VEGETABLES IN THE STATE OF NEW YORK: A CASE STUDY
}

\author{
Humberto Davi Zen ${ }^{1 *}$; Janaína Balk Brandão ${ }^{\text {1** }}$ \\ ${ }^{1}$ Postgraduate Program in Rural Extension, Federal University of Santa Maria, 97105-900, Santa Maria-RS, Brazil. \\ *humbertozen@gmail.com \\ **janainabalkbrandao@hotmail.com
}

Submitted at 28/02/2018 and accepted at 07/04/2018

\begin{abstract}
The aim of this paper is to analyze the production and marketing structure of a certified family establishment for organic food production in New York State and compare it with the scientific literature. In order to establish a high coordination between the production and commercialization processes, the farmer uses a productive and business planning supported by detailed records of previous seasons and sales and constant attention to the movements and trends of the markets and of the consumers of his products. Thus, it is verified that the
\end{abstract}

productive activities are oriented by a schedule elaborated according to the expectations of demand for each moment of the productive season. On the marketing side, organic certification proves to be a competitive advantage and a way of adding value to the product, and it enables access to different marketing channels, what allows the farmer to reach different groups of consumers. In this case, the direct marketing, especially in the Farmer's Market, is the most relevant marketing channel for both amount of products and revenue share.

KEYWORDS: horticulture, alternative markets, farmer's markets, online sales, certification.

\section{ANÁLISE DA PRODUÇÃO E COMERCIALIZAÇÃO DE HORTALIÇAS ORGÂNICAS NO ESTADO DE NOVA YORK: UM ESTUDO DE CASO} \section{RESUMO}

O objetivo deste trabalho é analisar a estrutura de produção e comercialização de um estabelecimento familiar certificado para produção de alimentos orgânicos em Nova York e confrontá-lo com a literatura científica. Para estabelecer uma alta coordenação entre os processos de produção e comercialização, o agricultor se vale de um planejamento produtivo e de negócios sustentado por registros detalhados de safras e vendas anteriores e da constante atenção aos movimentos e tendências dos mercados e dos consumidores de seus produtos. Com isso, verifica-se que as atividades produtivas são orientadas por um cronograma elaborado a partir das expectativas de demanda para cada momento da estação produtiva. Pelo lado da comercialização, a certificação orgânica mostra-se como uma vantagem competitiva e forma de agregação de valor ao produto, e possibilita o acesso a diferentes canais de comercialização e, que o permite alcançar diferentes grupos de consumidores. Neste caso, a comercialização direta, especialmente a realizada através da feira, é o canal mais relevante tanto em quantidade de produtos quanto em participação nas receitas.

PALAVRAS-CHAVE: horticultura, mercados alternativos, feiras de produtores, vendas online, certificação. 


\section{INTRODUCTION}

The increase in the life expectancy of the world population, mainly as result of the evolution of medical science, has made the focus of health-related concerns change. Later illnesses (caused by unhealthy habits) became the obstacle to longevity and quality of life. One of these factors is the food quality, and the healthier the eating habits, the greater the health benefits and disease prevention (MADAIL et al., 2015).

At the same time, the world's population increased from 3 billion in 1960 to 7.3 billion in 2015 (WORLD BANK, 2016). This growth in food demand forced agriculture, the largest natural food source, to increase its production volume, what lead to the Green Revolution. Thus, the conventional production system became dominant in Brazil and in the world. Nowadays, conventional agriculture is considered as an inefficient user and polluter of natural resources (FAO, 2015), and it also degrades the environment, accounting for $14 \%$ of the total world emissions of greenhouse gases (PACHAURI; MEYER, 2014). In addition, it intensifies the process of social differentiation in the rural environment, excluding producers with limited area availability, little capital for investments and little capacity for technology employment in the production (REDIN, 2015).

Recently, movements of demand and consumption behavior of individuals who are more aware about topics such as sustainability, human health and nature preservation related to the products they consume enabled the growth of the organic production. An example of this is how the United Nations (UNO) emphasized the organic agriculture at COP21 and in the development of global goals for sustainable development by 2030, pointing it as a way to fight hunger, poverty, misuse of natural resources and climate change, making food production and consumption a more sustainable process (IFOAM, 2015). Dias et al. (2015), seeking to understand the values that guide consumer choices, found that the attributes most commonly associated with organic products are sustainability, health, legitimacy, certification and food safety.

Currently, organic agriculture is present in $76 \%$ of the countries of the world and occupies 43.6 million hectares, which represents $1 \%$ of the world agricultural area (WILLER; LERNOUD, 2016). In 1999, its global market involved 200,000 producers and an amount of US\$ 15.2 billion. In 2014, it involved 2.3 million producers and an amount of US \$ 80 billion, of which US\$ 35.9 billion correspond only to the United States market share. It means that in the last 15 years, the market growth was greater than 500\% (WILLER; LERNOUD, 2016).

The Brazilian certified organic production is still small, with 11,650 registered producers, distributed over 750,000 hectares, but it is estimated that there are more than 4 million hectares cultivated without certification (WILLER; LERNOUD, 2016). In Brazil, it involved about R\$ 2 billion in 2014, with an expected growth rate of $20-30 \%$ by 2016 , closing the year at $\mathrm{R} \$ 2.5$ billion (MAPA, 2015). For comparison purposes, the 20 main cultivated grain crops in Brazil occupied 58 million hectares and mobilized R $\$ 309$ billion in 2015 (PORTAL BRASIL, 2015). According to Madail (2015), the agriculture model, based on commodities production with low resource use efficiency and low value-added for export, is the main reason for the little numbers observed in the primary sector of Brazil.

In this context, vegetable production is an income alternative for small producers due to the high investment returns per cultivated area due to the possibility of several harvests throughout the year and the demand for the family workforce available of the establishments. (MELO; VILELA, 2007). According to Camponhola and Valarini (2001), organic products have niche marketing characteristics, and therefore access markets willing to pay values about $30 \%$ higher than the prices practiced in the regular market (MAPA, 2015), compensating the yields 10 to $15 \%$ lower than those conventionally grown (LOTTER, 2003). Moreover, the producer tends to sell his products to the 
local market, which facilitates interaction with consumers and adaptations to its requirements, strengthening trust and credibility relationships between the parties (SCNHEIDER, 2016). Finally, due to high demand for labor, great diversity and specificity of the cultivated species, such as medicinal herbs and vegetables, some segments of the organics market are not interesting for large producers, decreasing competition (MELO; VILELA, 2007).

In Brazil, 90\% of organic producers are family farmers (BADUE, 2007). They produce $70 \%$ of the products marketed, while the remaining 30\% come from agricultural establishments with hired labor and high capital investments. In addition to the economic motivation, the lower need for capital to perform the activity, little dependence on external resources, the possibility of not having contact with chemicals, and the personal satisfaction of offering a healthier and more sustainable foods are also pointed out as influential elements in the option of organic farmers (SEDIYAMA et al., 2014).

According to Gemma et al. (2010), among the aspects that affect the efficiency and productivity of the organic system in a family farm, the fact that the producers are simultaneously responsible for the production (soil tillage, planting, cultivation, harvesting and processing) and administration (certification, marketing and management of human and financial resources). So, managers are required to develop and connect diverse competencies so that he can satisfactorily fulfill all their obligations. As they gain experience and improve themselves, producers tend to adapt each activity to make it as efficient as possible. Then, we can infer that an establishment with an organic production system that works for almost two decades and is economically sustainable in a highly competitive context may have several things to share with beginning farmers or with those who seek to improve their practices.

Thus, the aim of this paper is to perform an analysis of the production and marketing practices of an organic fruit and vegetable producer with more than 20 years of experience in a highly competitive food market. As specific goals, it seeks to describe the practices of cultivation and preparation of products for sale, as well as logistics management and marketing processes. The establishment taken as case study is in New York State, United States, operating in the largest and most competitive organic food market in the world (WILLER; LERNOUD, 2016).

The justification for this study is related to the fact that Brazil has a expanding organics market, and analyzing experiences of producers that work in other contexts can help in the development of a greater market competitiveness of the Brazilian producers, since the location and the time of experience in the organics market held by the studied farm make it a relevant source of practical knowledge about the processes that compose organic agriculture. Also, due to the similarities of local climate during Spring and Summer seasons and to the fact that most of the species cultivated and consumed in New York and Southern Brazil, sometimes even being the same cultivar, the practices and experiences learned at the internship are valuable information for farmers of the states in the south of Brazil, such as Paraná, Santa Catarina and Rio Grande do Sul.

\section{MATERIAL AND METHODS}

Taking the objectives as reference, this research is of the descriptive type, and concerning the methodological procedures, we have a case study, since it seeks to describe in depth aspects referring to an object of study (GIL, 2008). Data collection was done using the Intensive Direct Observation technique, in the form of participant observation, where there was a direct experience in performing all the tasks described (LAKATOS; MARCONI, 1992). All the information is of the qualitative type, and it was obtained during informal conversations with the establishment manager 
regarding the practices of production and marketing of the products, as well as the necessary steps to obtain the organic certification, being recorded in field notes and photographs.

The data collection period was from May and August 2015, through the completion of a professional internship with a total duration of ten weeks, which was complementary to a nondegree scholarship promoted by the Brazil Scientific Mobility Undergraduate Program, sponsored by the Coordination of Higher Education Personnel Improvement (CAPES).

The sequence of the present paper is a brief description of the establishment analyzed, which explains some of the main characteristics of the object of study. The next chapter is a bibliographic review divided into two sections, one of them referring to the notion of organic production and aspects of certification processes, while the second section deals with the commercialization of organic foods.

\subsection{DESCRIPTION OF THE ANALYZED ESTABLISHMENT}

The farm is in the rural area of Ellenville - New York, United States. The US market is responsible for $40 \%$ of the US\$ 80 billion traded by the organic market in the world (WILLER; LERNOUD, 2016). By 2014, New York state had real GDP of US\$ 1.28 billion, the third largest in the country (BRODA; TATE, 2015). The State economy is mainly based on service and industry sectors, and the agricultural production occupies about $25 \%$ of the state territory. According to the New York State Department of Agriculture (2016), New York ranks among the top five US agricultural producers of apples, wine, dairy, beef and cabbage. The region where the establishment is inserted follows the same economic model of the State, with industry and services dominating the economy, presenting little agricultural vocation. In this context, most people, even the rural population, choose to work in the urban areas and acquire most of the vegetables and meat they consume from third parties, creating a demand and an economically attractive market for local food producers.

Located ten miles away from the nearest town, Ellenville-NY, the farm has no road access issues, as all the roads in the area are paved and in great condition. The owner of the farm and his wife, plus two of their three children, live in the establishment. Of them, only the father dedicates in full-time to the organic production, assisted by two hired employees, while the other family members work professionally in the urban area. Retired from the banking sector of Manhattan, the owner has chosen the farmer career because of the affinity he feels for nature and his environmental ideals.

Due to the rigorous winter, which usually has snow covering the landscape, the production is only possible from Spring until the mid-Autumn, that is, from April to October, depending on the temperatures of that year. During the winter, the only destination of the production is the food demands of the family.

The start of the production in the area, already with commercial objective, occurred in 1996, and the organic certification was obtained in 2003. The total area of the establishment is 35 hectares, of which only two are dedicated to the production of vegetables, and eventually edible flowers, and about one hectare is occupied by buildings, lawns and gardens. The rest of the establishment area is covered by dense native forest, what creates a biological barrier from the farms around.

About $90 \%$ of the production is made in the open field, and $10 \%$ is done in the greenhouse, using exclusively seedlings produced on the property. All the products harvested go through the process of selection, washing and packing in the own establishment before being commercialized. Besides vegetables, eggs, blueberries and surplus seedlings are also sold. Chickens are fed with 
processing discards from vegetables. Blueberry is collected from wild forest plants during its natural harvest season, which starts in June and lasts about three weeks.

According to soil analyzes obtained by the farmer, the establishment has deep soil, silty and with some pebbles, slightly acidic ( $\mathrm{pH} \mathrm{5.7,} \mathrm{on} \mathrm{average).} \mathrm{The} \mathrm{entire} \mathrm{cultivated} \mathrm{area,} \mathrm{which} \mathrm{slopes}$ between $2 \%$ and $10 \%$, has abundant irrigation through a fixed sprinkler system, whose water supply comes from a pond located in the farm. The owner reports that he never had any water shortage issues, even during the Summer season. All the internal logistics of the farm is made using a minitruck that carries small loads, like trays of seedlings or boxes with harvested products. It reduces the time spent on transport processes and the physical wear and tear of workers, who do not have to manually carry loads over long distances.

\section{LITERATURE REVIEW}

\subsection{THE ORGANIC PRODUCTION SYSTEM}

The recent history of agriculture is marked by great technological revolutions. The first of these took place between the fourteenth and nineteenth centuries through the intensification of production processes, based not only on the increased use of green manures and crop rotation, but also on the evolution of agricultural equipment, such as the use of motorized traction (MAZOYER; ROUDART, 2010). Later, between the 60s and 70s, a new agricultural revolution took place, including not only the diffusion and implantation on a global scale of the techniques from first revolution, but also the creation and consolidation of a very intensive productive model based in the use of chemical inputs, such as fertilizers and agrochemicals, and in the mechanization of agricultural activities (ALBERGONI; PELAEZ, 2007). According to the same authors, in the 1980s this second agricultural revolution went through a new stage, with the emergence and expansion of the genetic manipulation of living organisms. This evolutionary process culminated in what is now known as conventional agriculture, which through agrochemistry, motorized mechanization and genetic manipulation transformed the relationship between man and nature, which was a close connection and interdependence before, towards a system of increasing human domination over nature (JESUS, 2005; GRAZIANO DA SILVA, 1996).

The results of both agricultural revolutions are controversial. On the one hand, there was a considerable increase in the productivity of agriculture and livestock, as well as an increase in the productivity of the farmer's work, with positive results in the context of a population growth and a higher demand for food. On the other hand, there are negative effects on several dimensions of agricultural production, such as: a) socioeconomic impacts, such as rural exodus and concentration of land and income, due to the decrease of the market value of agricultural products and credit policies which emphasized modern agriculture techniques (CAMPOS, 2016); b) environmental impacts: ranging from those at the local level, such as physical and chemical degradation of the soil and contamination of natural resources with fertilizers and agrochemicals, to the global level through the emission of polluting gases and compromise of air quality (BITTENCOURT , 2009); c) impacts on human health: represented not only by the effects of contamination of food by agrochemicals, but also by the formation of unbalanced food habits (CAMPOS, 2016).

Although its existence is previous to the agricultural revolutions, it was during and after the Second Green Revolution that the approach to sustainability in agriculture was consolidated. As a major exponent of this notion of sustainability we have Agroecology, which in essence treats the environmental, social and economic spheres from a holistic, unifying and integrating perspective (JESUS, 2005). For Caporal (2009), this interpretation of agriculture as a human and ecological process reconstructs the notion of relations of mutual dependence and influence between humans 
and nature. In this way, organic food production, by following the precepts of agroecology, can be treated as a form of "agroecological-based agriculture" (CAMPOS, 2016).

One of the milestones in the establishment of the notion of organic production was the foundation of the International Federation of Organic Agriculture Movements (IFOAM) in France in the year of 1972, with a view to create standards in a context of growing supply of organic products on the European market. In this context, besides the prohibition of the use of pesticides and the imposition of restrictions on the use of chemical fertilizers, elements about the conservation of natural resources and ethical aspects of the social relations were involved in production and commercialization notions (KHATOUNIAN, 2001). Currently, according to IFOAM (2016), there are four principles of organic agriculture: a) health: it seeks to maintain the health of soils, plants, animals, man and the planet; b) ecology: organic agriculture is based on the harmonization of biological cycles, where crops, livestocks and extractivism practices must adjust to natural ecological cycles; c) fairness: it aims the equality and the common good, seeking respect, justice and responsibility in the management of the shared environment; d) care: there must be planning and development of agriculture in a way that it protects the health and well-being of current and future generations, as well as the quality of the environment.

In the section 3.1.1, regarding organic certification, an analysis is made about whether these four principles are actually contemplated by the organic certification process in the contexts of Brazil and the United States. According to Sediyama et al. (2014), in the production of vegetables, the perspective of organic production serves as reference for practices such as soil management and fertilization, seedling production, use of green manure, crop rotation and intercropping, weed, pests and diseases management, as well as the handling and processing of the food after its harvest, always aiming at the good management of the energy flows of the system and the sustainability of agroecosystems.

\subsubsection{Certificação orgânica no Brasil e nos Estados Unidos}

According to Renting et al. (2003), there are two types of quality convention that guide the choices of food consumers. The first is the notion of territoriality and food tradition, while the second is linked to the bioprocesses of food, this being the one that includes organic foods. For the authors, the trust involved in the choice made by the consumer can be influenced by informations regarding the analyzed product, which can be obtained in two main ways. The first is the informal way, as in the case of direct social interactions with producers and other consumers, and the second one is the formal way, through control and certification seals attached to products or displayed at the point of sale. According to Kneafsey et al. (2013), the approximation between production and consumption allows a judgment of values about the food purchased, and the information about the products that reaches the consumer ends up becoming more important than the physical distance traveled or the number of agents along the production chain.

The point of view here proposed is that the organic certification is a form of communication with the consumer, where it is ensured that the certified product is in accordance with institutionalized rules and regulations. Therefore, the increase in the market competitiveness of a product with organic seal will depend essentially on the impact that expectations related to food bioprocesses have on consumer buying behavior, as well as on the consumer's trust in the legitimacy of the certification system.

Comparing the production and commercialization of organic foods regulations in Brazil Decree $N^{\circ} .06323$ of December 2007 (BRASIL, 2007) - and the United States - Organic Foods Production Act of 1990 (AMS, 2005) - there is a consensus on norms and notions of what is an 
organic cultivation system and an organic product. In both legislations, the use of synthetic substances (fertilizers and pesticides), antibiotics and genetically modified organisms is restricted, emphasizing the importance of the use of crop rotation, green manuring and other techniques that reduce the dependence of nonrenewable resources and with origin from outside the establishment. In the Brazilian case, there is also an indication that the organic production system must respect the cultural integrity of the communities in which it is performed, so that whenever possible it uses local natural and socioeconomic resources to increase ecological and economic sustainability. Thus, although the focus on the ecological and environmental dimensions of production in both countries are very similar, the Brazilian legislation gets closer to the agroecological principles than the American one does.

Another similarity between the two countries refers to the certification process itself, where it is necessary for the farmer interested in obtaining certification to contact an accrediting agent linked to the Ministry or Department of Agriculture to prepare a management plan for the system productive, which will be analyzed and later will serve as the basis for field inspections in the establishment. In the United States, organic certification form is through auditing, performed by "certifying agents" credited and authorized by the USDA National Organic Program, being associations of producers, private agents, among other types of organization. After registration in the national list of producers and payment of the fees, the farmer submits his production management plan elaborated in accordance with the organic production regulations. The next step is the field inspection performed by the certifying agent, and once the approval is obtained, the organic product seal is issued, which allows the marketing of products in all types of marketing channels of the domestic market of the country. The organic seal chosen to identify the products can be the official certificate of the United States Department of Agriculture (USDA) or the certifying agent's own seal, if it has its own regulatory system, which must be at least as rigorous as national regulations. Finally, certification is maintained through the annual renewal of the organic management plan and a new field inspection by the accredited inspector (USDA, 2018).

In the case of Brazil, certification can be obtained in three different ways, what allow different modalities of access to markets. The first format is that by auditing, where the process is the same as the American case. The second possibility is through a Participatory Guarantee System (PGS), where the certification is performed by a Participatory Organic Conformity Assessment Organization (PCAO). In this case, the producer must be an active member of an organization of agents involved in organic production, and the guarantee of compliance with the legislation is issued by the group itself, which monitors and supervises each other. In these two systems, the federal seal of organic compliance is issued, and it gives access to all types of marketing channels in the national market. Finally, there is the Social Control Organization (SCO), where a group of producers register on the Ministry of Agriculture and the guarantee of organic compliance of each producer is given by the other members of the group. In this case, they are authorized to sell their products only through direct sales and to institutional markets, not being issued the federal seal but a certificate of participation in an SCO that guarantees the organic quality of those products (BRASIL, 2008).

\subsection{MARKETING CHANNELS FOR ORGANICS}

Determining the best market option for farmers is a challenging task nowadays. Specifically, at a time when product differentiation plays a central role as consumers are increasingly demanding. However, in order for the farmer to choose the most suitable channel for his needs, whether it is direct, indirect or long (SPROESSER; LIMA FILHO, 2007), the following factors stand out: the time it will take to perform the marketing and the costs of the marketing process; the value added to 
the price paid to the farmer; the availability of labor (family or hired) to carry out the commercialization; personal 'identification' with the activity (including pleasure or satisfaction in performing certain activity).

Direct marketing channels such as farmers markets and community-supported agriculture (CSA) can enable family farmers to establish economically viable production systems, gaining access to higher priced markets, and reduce marketing uncertainties by building more localized food systems (STEPHENSON; LEV, 2004; BROWN et al, 2007). Thus, direct sales, whether through farmers markets or home sales are mechanisms commonly used by organic producers, characterizing themselves as an important market channel for family farming (PADUA-GOMES; GOMES; PADOVAN, 2016).

However, studies are concerned about the fact that the producer spend a significant amount of his working time with the commercial activities, putting in second plan the primary productive activities (THILMANY; WATSON, 2004). In addition, the costs involved in direct marketing activities (labor, purchased goods and services, and capital assets associated with these marketing activities) are considered significantly higher for farmers in direct channels (HARDESTY; LEFF, 2009). Neverthless, significant labor costs for the marketing activity and transportation costs were offset by the higher sale prices and low packaging costs associated with direct markets (HARDESTY; LEFF, 2009). According to a research conducted in California (USA), direct marketing is considered more profitable by $63 \%$ of producers (KAMBARA; SHELLEY, 2002). In order for farmers to be profitable, it is necessary to comply with packaging and classification standards, to use sale devices such as demonstration of products or prizes to consumers, clearly demonstrating the need for superior quality and differentiation strategies (HARDESTY; LEFF, 2009).

In an evaluation of the producers' satisfaction, they were satisfied with their returns in the direct channel, just paying attention to their productive capacity to offer sufficient volumes at reasonable prices (GOVINDASAMY et al., 2003). However, they point that harvesting, packaging, loading, transportation, promotional activities and divulgation, etc. are labor-intensive activities and require qualification (GOVINDASAMY et al., 2003). Thus, the producer needs to be aware that the direct market requires more effort than wholesale.

Analyzing the performance and marketing strategies of organic and/or agroecological farmers, it was found that $68 \%$ of the farmers feel satisfied and $32 \%$ very satisfied with the activity and direct marketing, and they pointed out the logistics from the field until the farmers markets as the main found difficulty (SANTOS et al, 2017). For the authors, the explanation lies on the fact that the relationship between farmer and consumer goes beyond the marketing process. A relationship of trust between the parties is established, what favors the transaction of products and benefits the process of adopting agroecological systems of production (ASSIS, 2002).

Among the particularities of the success potential of the shorter channels (especially when it comes to organic production), there is the fact that the producer gains market power by providing products to consumers with attributes that are not readily available in the conventional product distribution system (HARDESTY; LEFF, 2009). In addition, differentiated markets, such as those in familiar farmers markets, mainly through the sale of processed and organic products, are considered as spaces of social differentiation, especially in relation to the educational level of the consumers (SCHUBERT; SCHNEIDER, 2016).

In this sense, it is necessary to highlight a recent study on the independence of the choice of marketing channels and the income of organic producers in the United States, what concluded that although references point to the prioritization of direct channels by small producers, the distribution channels chosen, whether direct or indirect, are not tied to the producers' income, whether they are 
small or large (SCALCO et al., 2017). According to the paper, the choice of the appropriate channel is more related to the motivations of the producers in relation to the quality of life and growth prospects for their business, since such perspectives can influence the decision of which channels to access. In addition, the fact that direct channels demand a greater amount of activities to be performed by the producers themselves to enable the distribution of their products causes many of them to opt for indirect channels (SCALCO et al., 2017). They also emphasize that, by marketing their products through intermediaries, such food distributors as wholesalers, there is greater certainty of sale of the products, due to the commitment made between the parties through formal or informal agreements. At the end, they advise that the producer should choose to work with more than one channel simultaneously, in order to diversify its distribution points and reduce the risks of the activity.

\section{RESULTS AND DISCUSSION}

This section is divided into two parts, which present practices developed in the establishment analyzed and bring informations obtained in the academic literature regarding the activities of production and marketing of organic products experienced during the internship.

The first item focuses on the cultivation practices of the production, where techniques and ecological and sustainable managements practiced in the establishment are highlighted. The topics discussed are soil preparation and management, seedling production, crop rotation and intercropping, and weed, pest and disease management. The second part of the results and discussion deals with the post-harvest and commercialization processes. In this moment, the experience of the farmer is analyzed according to the literature review previously exposed, what pointed out the determinants of the commercial behavior of producers of organic fruit and vegetables. Hereby, we seek to understand how the market strategy of the establishment analyzed influences the management of the processes of production and commercialization of the products.

\subsection{Management and cultivation practices}

\subsubsection{Soil management and fertilization}

Lima et al. (2011) cites that soil quality is the most influential component in the production of vegetables, and its management mainly regulates the physical-chemical environment that the plant will dispose for its development. Sustainable soil management assumes that its fertility needs to be maintained or improved using natural resources and biological activities. Thus, the organic producer must use alternatives that provide the nutrients supply, in a wide and diversified way, prioritizing nutrient cycling through crop residues and fertilizations, preferably through green manure, handling legumes or spontaneous plants. With this in view, the focus should be on practices that increase or enhance the biological activities of the soil.

In the field, the beds are leveled with height of ten centimeters and width of approximately 1.2 meters. Arranged perpendicularly to the slope of the terrain, they help in the control of erosion. Both the field crops and the greenhouse have the pathways of the beds covered with lawn, which is mowed when it reachs about 15 centimeters in height. The botanical composition of the pathways counts not only with grass, but also with several spontaneous herbaceous species. The height of cut is adjusted a little higher than normal precisely to maintain the cleaning of the area, but still enable the maintenance of herbs, which serve as shelter for natural enemies. Unwanted plants are always eradicated by hand from the pathways so they do not disperse seeds. 
Another function of the lawn is the physical barrier for the soil and restriction of nutrient leaching. The fertility that would be lost with the rains returns to the bed as organic matter, because at the beginning of every productive season the beds are moved laterally in about 10 centimeters, when a strip of the lawn is incorporated to the bed using a motorized mini tiller. The lawns also improve the water retention capacity of soil, as rainwater has less mobility on the ground. Trimming the lawn is also important for water management, since the larger the plant mass, the greater the evapotranspiration, which could make the paths a drain of the water contained in the sides of the beds.

The beds are prepared using a mini motorized tiller. The use of this equipment optimizes the use of labor and physically preserves the workers, who can handle other tasks. Another benefit of this machine is the capacity of reincorporation of the cultural remains just after the harvest, intensifying the cultivation and making that each bed can receive more harvests by productive period. The lower permanence of senescent material exposed to pathogens also decreases the maintenance of diseases and pests in the field, since it will not serve as a host or food for pests and diseases. The grinding followed by contact with the soil accelerates the cycling of the nutrients contained in the plants.

Some species of the Brassicaceae species are sown as the last crop before winter, such as mustard. These plants support snow cover and keep some in the soil during the winter, then being incorporated into the soil in early spring. The use of crucifers serves to supplement the soil with organic matter and sulfur, which will be available for crops after their rapid decomposition. Sfredo and Lantmann (2007) point this nutrient as a catalyst of the main reactions involving phosphorus in the plants, and therefore can increase the yield of the crops planted next.

Through partnership with Cornell University of New York, the grower performs annual nutrient analyzes using the leaves of the vegetables as samples, so he can plan the replacement fertilization of the nutrients extracted along with the products at each harvest. Before incorporation of the rest of the plants left in the field after the harvest, the fertilizers are distributed over the bed with a fertilizer distributor pulled by a small tractor, then the bed soil is tilled. Only organic fertilizers are used, being mainly those produced on the farm from cheap and available products of the region, such as poultry or bovine waste mixed with vegetable remains, which are then heaped together and covered with composting mat, being left there for at least 100 days. It is important to emphasize that the compound needs to be completely decomposed, as this process eliminates the pathogens present in the waste and reduces the risk of contamination of the plants by coliforms (Sediyama et al., 2011). In addition, the authors cite that a properly prepared compound presents organic matter transformed into humus and improves the soil structure and its nutrients, water and air storage capacity. When necessary, it is applied a supplemental fertilization through a mixture of rocks and shells compound prepared by the farmer himself, which formula is about 2-4-2 (nitrogen - phosphorus - potassium), achieved through adjustments over the years of learning and observation in the field.

\subsubsection{Seedlings production}

The quality of the seedlings is decisive for the performance of the crops, thus the production of seedlings is one of the most important steps of the production of vegetables. The producer chooses to be responsible for his own seedlings so he can have them available at their planting ideal point according to the pre-established production schedule. Also, it allows him to have lower costs and avoid the dependence on the deadlines or availability of external suppliers. 
Another motivation is the difficulty to find in the market seedlings that meet the requirements for organic certification due to the used substrates. According to the producer, most commercial substrates are not recommended for organic systems because they are not certified, and therefore not allowed by the certification agents due to the possibility of having anti-ecological compounds and synthetic fertilizers of high solubility as components. He also argues that this way he manages to have a completely organic seedling, since the seeds he buys were also grown organically. This is not practiced by most seedling suppliers due to the higher cost and also because the production system of the seeds used is not taken into account for organic certification.

As substrate, it is used a mixture composed by three parts of organic compost for a part of vermiculite is used. Initially, all species are distributed in trays of 128 cells. Smaller seedlings, such as lettuce, complete their development in these trays, while the larger seedlings, such as tomato and pepper, are later transplanted to trays with larger cells, where they grow until the moment of their planting in the field.

The whole process, from mixing of the substrate until the seedlings be ready for planting, is done in a greenhouse which is dedicated only for seedling production. Every day, all the seedlings receive manual irrigation according to their water needs in the early morning.

\subsubsection{Crops management}

\subsubsection{Irrigation}

According to the producer, Ellenville region has very irregular rainfall during the summer, so the use of irrigation serves to reduce the risk and guarantee high productive levels, since the crops yield is not subject to the variations of the local rainfalls. By meeting the needs of crops, it also ensures compliance with established schedules, as there will be no changes in vegetative cycles and delays in harvests due to occasional water deficits.

\subsubsection{Crop Rotation}

Vegetables often have many phytosanitary issues due to the attack of a wide variety of pests and diseases. Crop rotation consists in avoiding the cultivation of plants of the same species or family in the same area successively. This practice reduces the infestation of insects, fungi and bacteria in the area, facilitating their control due to the breakdown of their reproductive and life cycles. Therefore, crop rotation is essential if the garden is to remain highly productive and sustainable without having to rely on aggressive methods of control (SANTOS; CARVALHO, 2013).

In the farm, the criteria used to determine the sequence of cultivated species were the contrasts between one and the other. For example, after a crop that left little biomass in the soil, it was used a specie capable of replenishing the volume of plant residues through high production of green material. The farmer has a detailed file of records about the production area, where each plot is properly identified and has its historic, which includes all the species it received in the recent years. According to him, the main attention is given to plants that depend on crop rotation to not have disease issues, such as lettuce and tomato. These plants do not return to the same site without at least two cultivation cycles with different species, such as basil and parsley. In an experiment carried out at EPAGRI, Silva and Peruch (2014) apud SEDIYAMA et al. (2014) evaluated the effect of crop rotation on organic and conventional onion crops over three years, using sweet 
potatoes and oats as intervals. The rotation system yielded $17.4 \%$ and $33.3 \%$ more than monoculture in conventional and organic systems, respectively.

\subsubsection{Intercropping}

Another technique commonly observed during the internship is the intercropping, where two or more species occupy a certain area at the same time in. The interaction between them, since they are not antagonistic, results in increased profitability per unit of cultivated area, greater economic and biological stability of the agroecosystem, higher efficiency in the use of labor and natural resources (soil, water, nutrients, light) and reduction of the presence of weeds, pests and diseases (SANTOS; CARVALHO, 2013). In addition, the authors point out that the intercropping contributes to the stability of the rural activity, ensuring staggered harvests and providing additional income for the producer.

The two most widely used combinations of species are radish with carrot and tomato with basil. The radish and the carrot are sown on the same day, in parallel lines, being three of radish and two of carrot. Because the radish cycle is shorter, and the carrot takes longer to be harvested (about three weeks later), it is harvested even when the carrot is young and initiating the deposition of reserves in the roots. As the plants height is similar, there is attention to leave at least 20 centimeters of spacing between the rows, so the aerial part of the radish does not compromise the photosynthetic capacity of the carrot due to the reduction of the useful leaf area by shading.

The second combination is between tomatoes and basil. First, the tomato seedlings are planted, and about a week later, the basil is introduced. This interaction is always established inside greenhouse, and it is possible to smell the aroma of the basil in the whole environment. According to the owner, this would remove the pest insects. As pointed out by Carvalho et al. (2005), this really happens. Comparing the single cultivation and intercropping of tomato and basil crops, the results showed a $21 \%$ increase in basil yield when intercropped, and a $30 \%$ reduction in tomato yield when in consortium. However, in the single crop, the tomato showed a greater amount of fruits damaged by insects. It was concluded that the association of both plants increases the economic return per unit of cultivated area, and it also favors the development of tomatoes that are healthier.

\subsubsection{Weed control}

As vegetable production usually takes place on bare soil, there is intense emergence of weeds soon after the soil rests for a few days. Because the cycle of species of economic interest is short and they do not have much potential for competition with other plants, the impact of weeds on production can be significant. With this in view, great care is taken to prevent the entry of seedlings and seeds of unwanted plants into the farm, as well as the eradication of the specimens found in the paths and environments of the beds. In addition, planting seedlings is always done at most one day after planting, so that the seedlings can develop before the seeds of spontaneous plants start germinating.

For the control of plants that appear in the beds during the cycle of vegetables in the field, the organic system recommends mechanical control, either manually or through weeding. This is the method adopted by the owner, since the use of cover plants with allelopathic effect is out of question because of the time that them would be occupying the site, making it impossible to grow vegetables. The type of equipment used and the age at which weeds are controlled in the american farm differ from that observed in Brazil. Brazilian farmers usually make the weeding using a big hoe, which revolves the first three or four centimeters of the soil surface and therefore requires 
careful operation so as not to damage the roots of the vegetables. In Brazil, it is also common for weeds to be controlled at a young age, but already large enough that their roots have resistance to their separation from the soil. Under these conditions, weeding is usually little ergonomic and timeconsuming, requiring a high labor force per cultivated area because the hoe is relatively heavy to handle and control must be done within a short time to avoid critical infestation periods.

In the case of the described establishment, the control of the weeds is done just after their emergence, still when they are seedlings. The equipment used is similar to a regular hoe, but it has smaller dimensions. It is composed of a blade about ten centimeters wide and two high, coupled in a thin and elongated cable, as shown in Figure 1.

Figure 1 - Equipment used for weeding in the analyzed farm.

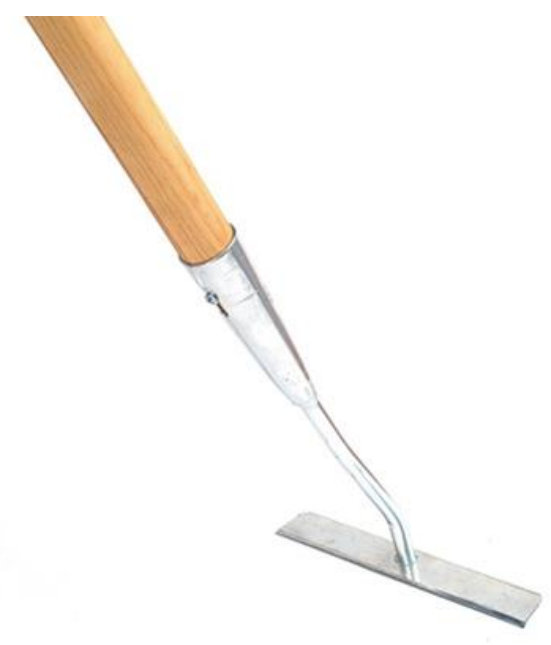

Source: JOHNNY SEEDS (2018).

Weeding is done by scraping the topsoil, which cuts the plants and scarifies the surface, improving the aeration of the soil. The little weight and easy to handle structure of the equipment, coupled with the small size of the plants to be controlled, makes the weeding operation faster and requires less labor effort. Therefore, the operational yield of weeding is much higher than that observed in traditional weeding. Another advantage is that no damage is caused to the roots of the vegetables. Only in extreme cases, when spontaneous plants get out of control, manual control is performed by pulling them out of the ground.

\subsubsection{Pests and diseases control}

Sediyama et al. (2014) states that in organic farming systems, pests and diseases should only be controlled when there is a risk of considerable damage to production. Then, the ideal action is to seek for the natural balance of the agroecosystem, using biodiversity-promoting practices such as polyculture, crop rotation and windbreaks, as well as seeking to increase soil organic matter content and balanced crop nutrition, in addition to other factors that allow an adequate management of the systems. Also, the location of the field can greatly benefit the integrated management, since the external sources of pathogens influence the pressure of pests and diseases on the crops. Since the 
analyzed field has a dense forest around it, there are no crop fields within a kilometer of the production area, and the traffic of vehicles and people by the place is reduced, there is practically no introduction of new organisms in the fields.

During the whole internship, there were no major issues with pests or diseases due to the biological balance of the system achieved after successive years of prevention and eradication of the presence of pests and infected tissues. The owner uses an interesting term to explain the essence of his actions against pests and diseases, saying that he handles them "passively". Thus, his only action has always been to eliminate and replace diseased plants with new seedlings, and he reinforces the importance of crop rotation to avoid problems. The only problematic pest was a leaf eating beetle, which attacks the crucifers making small holes in the leaves and making them unsuitable for commercialization. Dealing with this pest is relatively easy, since its life cycle is well known, with its damage period lasting two weeks, occurring monthly. As beetles develop on the ground and do not disperse much around the field area, the control method is to monitor where they are present, and consequently avoid planting crucifers on those specific beds.

Other practices also contribute to the observed scenario, such as the enormous biodiversity maintained in the field, especially in the lawns of the paths, which house many species of macro and microorganisms that act as natural enemies of the pest that may arise. The producer cites that the variety of species present on the lawn also serves as an attraction to pests, for there are plants many times more appetizing to insects than the vegetables of the beds.

Finally, we highlight an activity that plays a key role for plant health. From the production of the seedlings to the end of their cycle, the plants receive a weekly spray of a solution containing water mixed with extract of a seaweed called Ascophyllum nodosum. The extract of this seaweed acts on the control of phytopathogens by means of antimicrobial activity of its extracts, and also by inducting plant defense mechanisms and promotion of plant growth (DAPPER et al., 2014). The same author has found evidence that this product moderately increases plant tolerance to water deficit. Also, the extract contains about $17 \%$ of potassium in its composition, which characterizes the spraying also as foliar fertilization.

\subsection{POST-HARVEST AND COMMERCIALIZATION}

\subsubsection{Harvest and post-harvest}

Harvesting should be performed in the mild parts of the day, with lower temperatures and light solar radiation, so that the harvested material does not have very high respiration rates nor a rapid degradation and wilting. It is also necessary to avoid crushings, which compromises the integrity and shorten the viability of the vegetables (CENCI, 2006). The harvesting operation in the analyzed farm is always performed on Wednesdays and Fridays mornings. Once harvested, the products are transported out of the field conditioned in plastic boxes loaded on a mini-van, and taken to a small packing house. This unit consists on a tent that houses metal tables and wash tanks, plus an improvised washing machine that works as a vegetable centrifuge. The harvested products are cooled down and washed in cold and clean water, and then are selected. No disinfectants are used, since the producer believes that the vegetables come sufficiently clean from the field, and the use of such products is unnecessary and would make the food "less natural".

Finally, the vegetables are weighed and packaged according to the size of the pre-set unit sizes and destination. Products intended for sale to restaurants and supermarkets are individually packaged in plastic bags with origin identification and organic seal, and then placed in larger plastic boxes or 
bags to facilitate transportation. The vegetables destined for direct sale also receive individual packaging, and are packed in crates for transportation to the farmers market, where they will be freely displayed, or to the packaging unit of the product baskets purchased on the Online Store. Once packed, all the harvested production is stored in a cold chamber, where the internal temperature is kept around $12^{\circ} \mathrm{C}$, and remain there until the delivery or sale moment. All the previously described practices corroborate with what Cenci (2006) points in the EMBRAPA's manual for good fruit and vegetable harvesting practices.

\subsubsection{Commercialization}

\subsubsection{Use of multiple sales channels}

The analyzed farmer, when questioned about his sales strategy, emphasizes the importance of the coordination between the production and the commercialization in his establishment. First, he highlights the importance of organic certification. All plant production of the establishment is certified through affiliation to the Northeast Organic Farming Association/New York - NOFA/NY. In his opinion, certification is key for his negotiations and sales to be successful. First, it is a legal guarantee offered to establishments, such as restaurants and canteens, and second, it is another way of communicating to consumers the qualitative attributes of his products.

The production is sold through various marketing channels. The first one is an online sales platform, which makes deliveries to neighboring towns twice a week, on Wednesdays and Saturdays. This channel is what pays the best prices, and therefore has priority. The website belongs to the farmer, and it offers a wide variety of products. This is possible due to the association with other local certified organic farms, which provide beef, pork, fine herbs, honey, candles, dairy products made of goat milk, baked goods, jams, flowers, among others. Customers place the order online according to the list of available products on the website, what is updated by each producer, and make the payment in advance. On Wednesdays and Fridays, after harvest, baskets containing all ordered products are assembled, and during the following day the deliveries are made at several collection points in Ellenville and four neighboring towns, covering a 60-kilometer radius.

The second sales channel is the farmers market, which happens on Saturdays in KingstonNY, which has about 25,000 inhabitants. In this event, there are only two certified organic vegetable producers among more than 30 exhibitors. The farmer claims to feel rewarded through the experiences and ideas exchanges with consumers, what can be observed by his disposition and cordiality to explain details about his products that range from the cultivation process until the taste differences among the lettuce varieties or giving recipe suggestions with his products as ingredients, which corroborates the statements of Schubert and Schneider (2016). Because it is the sales channel in which contact with consumers is more intense, the producer has always highlighted the need to make customers feel good when visiting his tent, even if they do not buy anything. According to him, this would increase the rate of return of people for future purchases, and some details of his attention to the service quality at the farmers market can be observed in Figure 2.

Figure 2 - Sales tent in the Farmers Market 


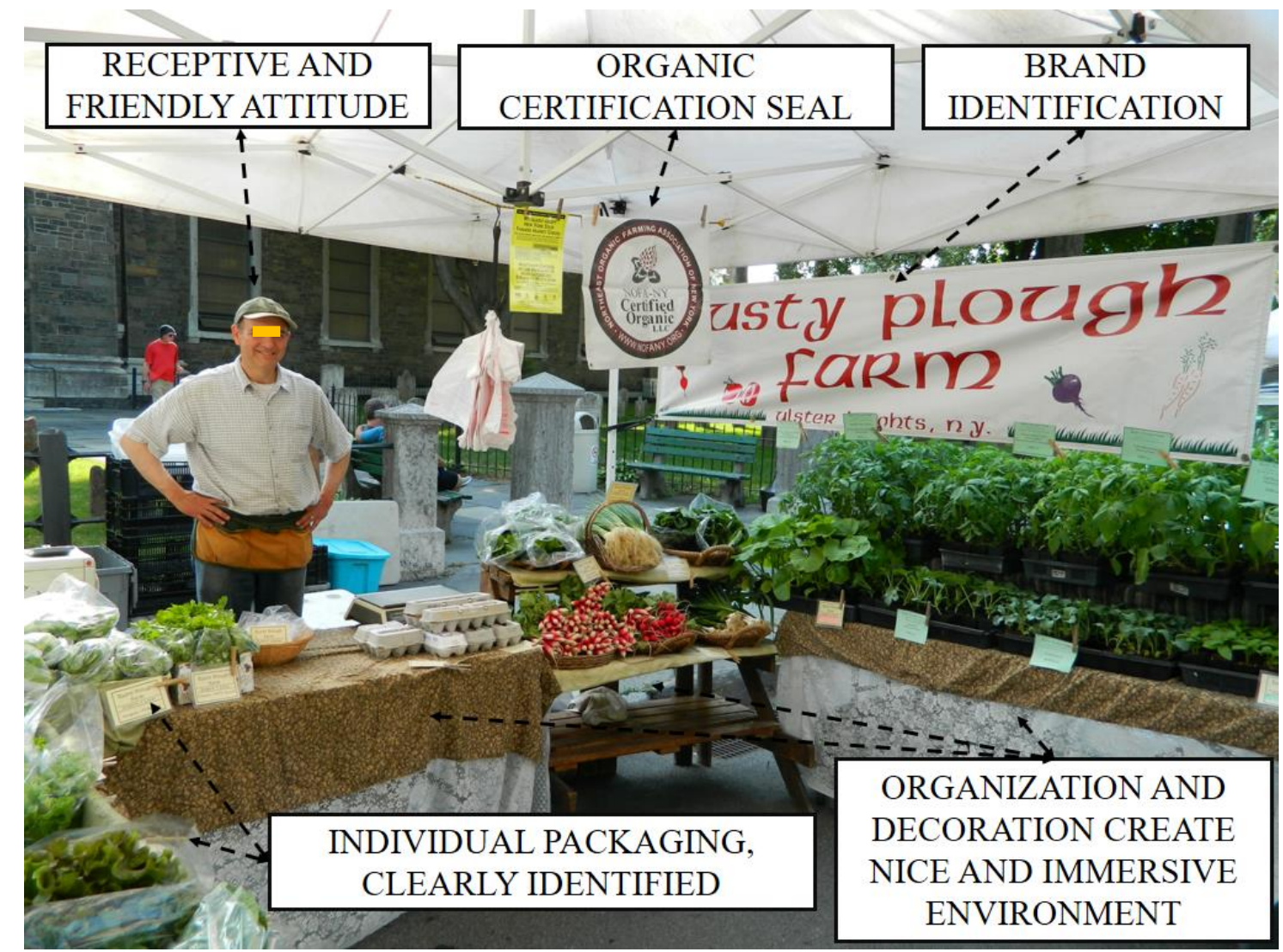

Source: Authors' collection.

The third form of commerce is the sale to supermarkets and restaurants. As they pay less, this trade option divides importance with the farmers market, so that although they receive almost the same volume of products, it contributes less to the total income. On Wednesdays, the entire harvest is directed to online and wholesale sales, accounting for about $40 \%$ of the total volume of produce harvested in the week, and on Fridays, the harvest is mostly destined for the farmers markets, and a smaller part to the other channels. Details about the amount of products destined to each marketing channel and the share of total revenues can be seen in Table 1. In the Brazilian scenario, the diversification, so defended by organic production, should also be part of the commercialization strategy, what can assume three main formats: a) direct sale to the consumer, in farmers markets, in the farm itself, home delivery, etc.; b) retail, through small businesses and supermarkets; c) wholesale, in hypermarkets and distributors (DAROLT, 2001).

Table 1 - Marketing channels

\begin{tabular}{lccc}
\hline Marketing Channel & $\begin{array}{c}\text { Number of transactions } \\
\text { (week) }\end{array}$ & $\begin{array}{c}\text { Sales share } \\
\mathbf{( \% )}\end{array}$ & $\begin{array}{c}\text { Revenue share } \\
(\mathbf{\%})\end{array}$ \\
\hline Farmers Markets & $90-120$ people & 40 & 45 \\
Online Sales & $40-70$ orders & 15 & 25 \\
Wholesale & 3 establishments & 35 & 30 \\
\hline Total & - & 100 & 100 \\
\hline
\end{tabular}

Source: Elaborated by the authors. 
Table 1 shows the predominance of the direct channel, represented by the farmers market and online sales (70\% of total revenues). Thus, by comparing wholesale sales to direct sales in relation to product volume and revenue share, it can be said that this particular farmer makes his marketing channel choices using criteria of economic rationality, what contrasts in part the claims of SCALCO et al. (2017).

\subsubsection{Creation of a brand and use of information}

The producer gives a lot of attention to the quality and identification of the products put on the market. He takes this seriously, as he wants to have his products and brand remembered as synonymous with high standards and trust. The use of the label with the farm name and organic seal identify the origin of the food sold and can captivate the preference of the customers. At the farmers market, the organization of each product on the bench is strategic. For example, placing the bunches of basil next to tomatoes increases the sales of both of them together as they are the main components of the typical Italian sauce, which is popular in the region. Another point is his instruction to never have just a few units of a certain product exposed at the tables, as this gives the impression that they are the "remnants" left by other customers. So the usual action is to bring more products than the sales expectation, creating a sense of "abundance and freshness", which does not reduce the pace of purchases of the products. The surplus products are then taken back to the farm for the family consumption or to be sold at lower prices to neighbors.

Also, the farmer also keeps a very complete database with records of years of observation of each marketing channel adopted, and with this he can anticipate certain movements of the market. For example, for the farmers market he records the number of transactions made every hour, as well as the total amount of products sold each day. With this, it is not only possible to predict the sales according to the weather of that day, but also to identify what species have the most appeal in each month of the year, and thus to program the availability of products suited to the demand at the right time. Two good examples are lettuce and kale. The first one sells more in early summer, because it is lighter and moisturizing food. Kale sells better with the arrival of autumn, when temperatures start going down and the consumption of soups and warmer recipes increases, where kale is an ingredient.

Keeping an eye on the media to detect consumer trends is another concern of his concerns. An example of this was his decision to grow edible flowers, which was quite successful for a few years after he read in a gastronomic column of the The New York Times Newspaper about how they would become fashion in the future. He bet on the idea and got ahead of the whole market, getting a great economic return by becoming the only available supplier to restaurants and supermarkets in the region.

\section{CONCLUSION}

This paper approached the context of an organic food producer from the United States, which, because it is part of a competitive market, is forced to seek for all its efficiency and profitability potentials with sustainability. In order to establish a high coordination between the production and commercialization processes, the farmer uses a productive and business planning supported by detailed records of the previous seasons and sales and by constant attention to the movements of the market and of the consumers of his products. Thus, it is verified that the productive activities are oriented by a schedule elaborated according to the products demand expectations for each moment of the productive season. 
On the marketing side, organic certification shows to be a competitive advantage and a way of adding value to the products, and it also opens access to different marketing channels and allows the farmer to reach different groups of consumers. In his case, the direct marketing, especially that performed through the farmers market, is the most relevant channel both in quantity of products and in revenue share.

\section{REFERENCES}

ALBERGONI, L; PELAEZ, V. Da Revolução Verde à Agrobiotecnologia: Ruptura ou Continuidade de Paradigmas? Revista de Economia, Curitiba, v. 33, n. 1, p. 31-53, jan./jun. 2007.

AMS. Organics Foods Production Act of 1990. Washington, DC: Agricultural Marketing Service - United States Department of Agriculture. 2005. 21 p. Available at: < https://www.ams.usda.gov/sites/default/files/media/Organic\% 20Foods\%20Production\%20Act\%20of\%201990\%20(OFPA).pdf>. Access in 06 feb. 2018.

ASSIS, R. L. Agroecologia no Brasil: análise do processo de difusão e perspectivas. Campinas. 2002. 150 p. Thesis (Doctorate in Applied Economics) - Universidade Estadual de Campinas, Campinas, 2002.

BADUE, A. F. B. Inserção de hortaliças e frutas orgânicas na merenda escolar: as potencialidades da participação e as representações sociais de agricultores de Parelheiros. São Paulo. 2007. 265 p. Dissertation (Master in Public Health) - Universidade de São Paulo, São Paulo, 2007.

BITTENCOURT, M. V. L. Impactos da agricultura no meio-ambiente: Principais tendências e desafios (Parte 1). Economia \& Tecnologia, Curitiba, PR, y. 5, v. 18, p. 133-146, jul./sep. 2009.

BRASIL. Decreto n. ${ }^{\circ}$ 6.323, de 27 de dezembro de 2007. Regulamenta a Lei n. ${ }^{\circ} 10.83$, de 23 de dezembro de 2003, que dispõe sobre a agricultura orgânica, e dá outras providências. Diário Oficial da República Federativa do Brasil. Brasília DF, 27 dec. 2007. Available at: <http://www.planalto.gov.br/ccivil_03/_ato20072010/2007/decreto/d6323.htm> Access in: 02 feb. 2018.

BRASIL. Mecanismos de controle para a garantia da qualidade orgânica. Ministério da Agricultura, Pecuária e Abastecimento. Coordenação de Agroecologia. - Brasília : Mapa/ACS, 2008. 56 p.

BRODA, J. E.; TATE, R. P. Gross domestic product by state. Survey of Current Business. Washington, DC, Jul. 2015. Available at: 〈http://www.bea.gov/scb/pdf/2015/07\%20 July/0715_gross_domestic_product_by_state.pdf〉. Access in: 23 jun. 2016.

BROWN, C. et al. The importance of farmers' markets for West Virginia direct marketers. Renewable Agriculture and Food Systems, Cambridge, v. 22, n. 1, p. 20-29, mar. 2007.

CAPORAL, F. R. Agroecologia: uma nova ciência para apoiar a transição a agriculturas mais sustentáveis. 1. Ed. Brasília: MDA/SAF, 2009. 30 p. ISBN: 978-85-60548-70-5.

CAMPOS, M. B. N. Impactos sociais, ambientais e econômicos da conversão para produção orgânica: o caso dos produtores de leite da bacia do Rio Paraná. Brasília, DF. 2016. 175 p. Dissertation (Master in Agribusinnes) Universidade de Brasília, Brasília, 2016.

CARVALHO, L.M. et al. Produção orgânica consorciada de tomate e plantas aromáticas ou repelentes. Aracaju: Embrapa Tabuleiros Costeiros. nov. 2005.

CENCI. S.A. Boas Práticas de pós-colheita de frutas e hortaliças. In: NETO, F.N. (Org.). Recomendações Básicas para a Aplicação das Boas Práticas Agropecuárias e de Fabricação na Agricultura Familiar. 1.ed., Brasília, DF: Embrapa Informação Tecnológica, 2006. p.67-80.

DAPPER, T. B. et al. Potencialidades das macroalgas marinhas na agricultura: revisão. Revista em Agronegócios e Meio Ambiente, Maringá, v. 7, n. 2, p. 295-313, may/aug. 2014.

DAROLT, M. R. O papel do consumidor no mercado de produtos orgânicos. Agroecologia Hoje, a. 2, n. 7, p. 8-9, feb./mar. 2001

DIAS, V. V. et al. O mercado de alimentos orgânicos: um panorama quantitativo e qualitativo das publicações internacionais. Ambiente \& Sociedade, São Paulo, SP, v. 18, n. 1, p. 161-182, jan./mar. 2015.

FAO. Statistical pocketbook: World food and agriculture, Rome - Italy: Food and Agriculture Organization of the United Nations - FAO, 2015. 236p. 
GEMMA, S.F.B.; TERESO, M.J.A.; ABRAHÃO, R.F. Ergonomia e complexidade: o trabalho do gestor na agricultura orgânica na região de Campinas-SP. Ciência Rural, Santa Maria, RS, v. 40, n. 2, p. 318-324, feb. 2010.

GIL, A. C. Métodos e técnicas de pesquisa social. 5 ed. São Paulo: Atlas, 206p. 2006.

GOVINDASAMY, R. et al. Producer satisfaction with returns from farmers market related activity. American Journal of Alternative Agriculture. Cambridge, v. 18, n. 2, p. 80-86, 2003.

GRAZIANO DA SILVA, J. A Nova Dinâmica da Agricultura Brasileira. Campinas: UNICAMP, 1996.

HARDESTY, S. D.; LEFF, L. Determining marketing costs and returns in alternative marketing channels. Renewable Agriculture and Food Systems, Cambridge, v. 25, n. 1, p. 24-34, 2009.

IFOAM. Into the future: Consolidated annual report of IFOAM. Bonn, Germany: Organics International, 2015. 24p.

IFOAM. Principles of organic agriculture. 4p. 2016.4 Available at: <https://www.ifoam.bio/sites/default/files/poa_english_web.pdf>. Access in 01 feb. 2017.

JESUS, E. L. Diferentes Abordagens de Agricultura Não-Convencional: História e Filosofia. In: AQUINO, A. M de. ASSIS, R. L. (Ed.) Agroecologia Princípios e Técnicas para uma Agricultura Orgânica Sustentável. Brasília: Embrapa Informação Tecnológica, 2005.

JOHNNY SEEDS. Standard Collinear Hoe - 7" Fixed Blade. Johnny's Selected Seeds. Maine, 2018. Available at: <http://www.johnnyseeds.com/tools-supplies/long-handled-tools/hoes/collinear-hoes/standard-collinear-hoe-7\%22fixed-blade-9093.html>. Access in 06 feb. 2018.

KAMBARA, K. and SHELLEY, C. The California Agricultural Direct Marketing Study. Davis, CA: USDA-AMS and California Institute of Rural Studies, 2002.

KNEAFSEY, M. et al. Short food supply chains and local food systems in the EU: a state of play of their socioeconomic characteristics. European Commission. Joint research center. Institute for prospective technological studies Publication office of the European Union. 2013.

KHATOUNIAN, C. A. A reconstrução ecológica da agricultura. Botucatu: Agroecológica, 2001.

LIMA, P.C. et al. Manejo da adubação em sistemas orgânicos. In: LIMA, P.C. et al. Tecnologias para produção orgânica. Viçosa, MG: Unidade Regional EPAMIG Zona da Mata. p. 69-106, 2011.

LOTTER, D.W. Organic Agriculture. Journal of Sustainable Agriculture, Kutztown - PA, v. 21, n. 4, p. 59-128, 2003.

MADAIL, J. C. M.; BELARMINO, L. C.; BINI, D. A. Evolução da produção e mercado de produtos orgânicos no Brasil e no mundo. Revista Científica da AJES. Vale do Juruena, v. 2, n. 3, 2011. Available at: <http://www.revista.ajes.edu.br/index.php/RCA/article/view/ 52>. Access in: 23 jun. 2016.

MAPA. Mercado brasileiro de orgânicos deve movimentar R\$ 2,5 bi em 2016. Brasília: Estatísticas Agrícolas Ministério da Agricultura, Pecuária e Abastecimento, oct. 2015 . Available at: <http://www.agricultura.gov.br/comunicacao/noticias/2015/09/mercado-brasileiro-de-organicos-deve-movimentar-rs-2bi-em-2016>. Access in: 20 jun. 2016.

MELO, P. C. T.; VILELA, N. J. Importância da cadeia produtiva de hortaliças. Associação Brasileira de Horticultura, 2007. Available at: <http://www.abhorticultura.com.br/downloads/cad eia_produtiva.pdf>. Access in: 06 jun. 2017.

PORTAL BRASIL. Valor bruto da produção agropecuária de 2015 é de R\$ 481,4 bilhões. Brasília: Portal Brasil Produção Agrícola, oct. 2015. Available at: <http://www.brasil.gov.br/economia-e-emprego/2015/10/valor-bruto-daproducao-agropecuaria-alcanca-quase-r-500-milhoes-em-2015>. Access in: 06 feb. 2018.

MARCONI, M. A.; LAKATOS, E. M. Fundamentos de metodologia científica. 5.ed. São Paulo: Editora Atlas S.A., 2013. 310p.

MAZOYER, M; ROUDART, L. História das Agriculturas no Mundo: Do Neolítico à Crise Contemporânea. São Paulo: Editora UNESP; Brasília: NEAD, 2010.

PACHAURI, R. K.; MEYER, L. A. (Eds.) Climate Change 2014: Synthesis Report. Contribution of Working Groups I, II and III to the Fifth Assessment Report of the Intergovernmental Panel on Climate Change., Geneva - Switzerland: Intergovernmental Panel on Climate Change, 2014. 151p. 
PADUA-GOMES, J. B.; GOMES, E. P.; PADOVAN, M. P. Desafios da comercialização de produtos orgânicos oriundos da agricultura familiar no estado de Mato Grosso do Sul. Revista Brasileira de Gestão e Desenvolvimento
Regional,
Taubaté,
12 ,
n. $\quad 1$,
p. 132-156
2016.
Available
at: <http://www.rbgdr.com.br/revista/index.php/rbgdr/article/view/2124>. Access in 03 feb. 2018.

REDIN, E. Construção social de mercados: a produção orgânica nos assentamentos do Rio Grande do Sul, Brasil. Interações, Campo Grande, v. 16, n. 1, p. 55-66, jan./jun. 2015.

RENTING, H.; MARSDEN, T.; BANKS, J. Compreendendo as redes alimentares alternativas: o papel de cadeias curtas de abastecimento de alimentos no desenvolvimento rural. In: GAZOLLA, M.; SCHNEIDER, S. Cadeias curtas e redes agroalimentares alternativas: negócios e mercados da agricultura familiar. Porto Alegre - RS: Editora da UFRGS, 2017. $520 \mathrm{p}$

SANTOS, D. S. C. et al. Desempenho de agricultores familiares na comercialização de produtos orgânicos e agroecológicos no estado do Pará. Acta Biológica Catarinense, Joinville, v. 4, n. 2, p. 16-29, 2017.

SANTOS, I. C.; CARVAlHO, L. M. Produção sustentável de hortaliças. Circular Técnica EPAMIG, n. 182, apr. 2013. $5 \mathrm{p}$

SCALCO, A. R. et al. A Independência da Escolha dos Canais de Marketing nas Rendas dos Produtores Orgânicos Americanos. Revista de Economia e Sociologia Rural, Brasília, v. 55, n. 4, p. 767-782, 2017. Available at: <http://www.scielo.br/scielo.php?pid=S0103-20032017000400767\&script=sci_arttext>. Access in 03 feb. 2018.

SCHNEIDER, S. Mercados e Agricultura Familiar. In: Construção de Mercados e Agricultura Familiar: Desafios para o Desenvolvimento Rural. Porto Alegre: Editora da UFRGS, 2016. Chapter 4, p.93-140.

SCHUBERT, M.; SCHNEIDER, S. Construção social de mercados e as tendências de consumo: o caso do Pavilhão da Agricultura Familiar da EXPOINTER (RS). Ciências Sociais Unisinos, São Leopoldo, v. 52, n. 3, p. 373-382, set./dez. 2016. Available at: <http://www.r edalyc.org/html/938/93849899009/>. Access in 03 feb. 2018.

SPROESSER, R. L.; LIMA FILHO, D. O. Varejo de alimentos: estratégia e marketing. In: Gestão Agroindustrial. Org. Batalha, M. O. 3 ed. São Paulo: Atlas, 2007.

SEDIYAMA, M.A.N. et al. Compostos orgânicos produzidos com resíduos vegetais e dejetos de origem bovina e suína. In: CONGRESSO BRASILEIRO DE AGROECOLOGIA, 7., 2011, Fortaleza. Anais $7^{\mathbf{0}}$ Congresso... Fortaleza, p. 1-5, 2011.

SEDIYAMA, M.A.N.; SANTOS, I.C.; LIMA, P.C. Cultivo de hortaliças no sistema orgânico. Revista Ceres, Viçosa, v. 61, sup. p. 829-837, nov./dec. 2014.

SFREDO, G. J.; LANTMANN, A. F. Enxofre: Nutriente necessário para maiores rendimentos da soja. Circular Técnica Embrapa, Londrina, n. 53, sep. 2007. 6p.

STEPHENSON, G.; LEV, L. Common support for local agriculture in two contrasting Oregon communities. Renewable Agriculture and Food Systems, Cambridge, v. 19, n. 4, p. 210-217, 2004.

THILMANY, D.; WATSON, P. The increasing role of direct marketing and farmers markets for western US producers. Western Economics Forum - Department of Agricultural and Resource Economics of Colorado State University, v. 3, n. 2, p. 19-25. apr. 2004

USDA. National Organic Program. United States Department of Agriculture - Agricultural Marketing Service. 2018. Available at: <https://www.ams.usda.gov/about-ams/programs-offices/national-organic-program>. Access in 05 feb. 2018.

WILLER, H.; LERNOUD, J. (Ed.) The world of organic agriculture: Statistics and emerging trends 2016. Frick Switzerland: Research Institute of Organic Agriculture (FiBL), Frick, and IFOAM, 2016. 340p.

WORLD BANK. World development indicators database. The World Bank. 2016. Available at: <http://data.worldbank.org/indicator/SP.POP.TOTL/countries/1W?order=wbapi_data_value_2011\%20wbapi_data_valu e\%20wbapi_data_valuefirst\&sort=asc\&display=graph>. Access in 15 jun. 2016.

This work is licensed under a Creative Commons Attribution 4.0 International License. 